\title{
Statistical Atlas of Poland and statistical atlases of voivodships
}

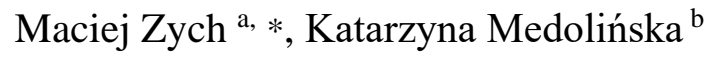 \\ a Statistics Poland, Spatial and Environmental Surveys Department, m.zych@stat.gov.pl \\ ${ }^{b}$ Statistics Poland, Spatial and Environmental Surveys Department, k.medolinska@stat.gov.pl \\ * Corresponding author
}

\begin{abstract}
In 2018, 100 years had passed since the Central Statistical Office of Poland (since 2017: Statistics Poland GUS) was established. This anniversary was considered an opportunity for preparation of a series of cartographic publications, i.e. 16 statistical atlases of Polish voivodships (first order administrative units) and the Statistical atlas of Poland. Publication of such a series of atlases is a new undertaking in the history of Polish statistics - it involved both the employees of the head office of Statistics Poland in Warsaw and the staff of statistical offices in 16 voivodships. Statistical atlases of voivodships and the Statistical atlas of Poland count 1888 pages in total with 2934 maps, on which the development of the country is presented in relation to regional and local conditions. All atlases are bilingual, PolishEnglish.
\end{abstract}

Keywords: Atlas, Statistical maps, Thematic maps

\section{Introduction}

In 2018, 100 years have passed since the Central Statistical Office of Poland (since 2017: Statistics Poland - GUS) has been established. This anniversary was considered an opportunity for preparing a series of cartographic publications, i.e. the Statistical Atlas of Poland and 16 statistical atlases of individual Polish voivodships (the first order administrative units). The publication of such a series of atlases is an undertaking that had never occurred in the history of Polish statistics - both the employees of the head office of Statistics Poland in Warsaw and statistical offices in 16 voivodships were involved.

The Polish public statistics could not boast about numerous of such publications till 2018. The first atlas publication of Statistics Poland was the Republic of Poland - Statistical Atlas released in 1930. There were included 63 maps and numerous charts on 42 map-pages. The next Statistical Atlas, covering all of Poland, was published only in 1970. This publication consisted of 204 pages, of which 163 pages contained maps (in total 150 maps, mainly choropleth and diagram maps) as well as charts and graphs. The next statistical atlases were published over 30 years later - six atlases of five voivodships (i.e.: Statistical atlas of Warmińsko-Mazurskie Voivodship 2005, Statistical atlas of social issues [of the Zachodniopomorskie Voivodship], Agricultural Census 2010. Atlas. Agricultural production in rural areas of Mazowieckie Voivodship, Statistical atlas of Lubelskie Voivodship 2012, National Census of Population and Housing 2011. Atlas of counties and communes of Mazowieckie Voivodship, Statistical atlas of Matopolskie Voivodship 2016), published in 2006-2016, and the Demographic Atlas of Poland published in 2017. The last atlas has 128 pages with 126 maps (mainly prepared using the methods of choropleth and diagram map) and 165 charts/graphs.

\section{Statistical Atlas of Poland}

The Statistical Atlas of Poland (Figure 1) was published at the beginning of July 2018. The principles on this publication were developed entirely in the Spatial and Environmental Surveys Department of Statistics Poland. 12 people worked on the preparation of the detailed conception of this atlas and on the selection of topics to be presented on particular maps and charts/graphs.

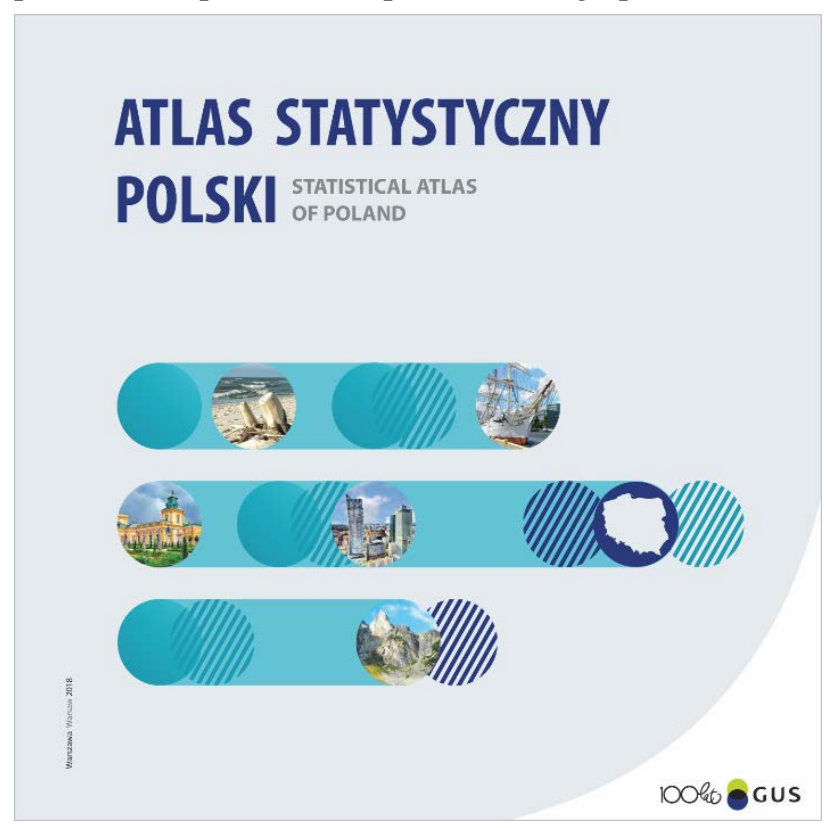

Figure 1. The cover of the Statistical Atlas of Poland. @ Statistics Poland 2018.

Seven thematic sections have been distinguished in the atlas: Location and Division (presenting Poland in Europe and various territorial divisions of the country used by the statistics), Human Capital (divided into three parts: 
Demography, Education and Skills, Labour Resources), Quality of Life (divided into eight parts: Situation of Households, Poverty and Social Exclusion, Housing, Health Care, Social Welfare and Family Support, Culture and Recreation, Public Safety, Civil Society), Economy (divided into five parts: Gross Domestic Product, Passenger Border Traffic, Public Finance, Entrepreneurship, Production and Services), Environment, Poland as Compared with the UE (data for EU countries or statistical regions of NUTS level 2), and Poland as Compared with the World (data for countries in the world).

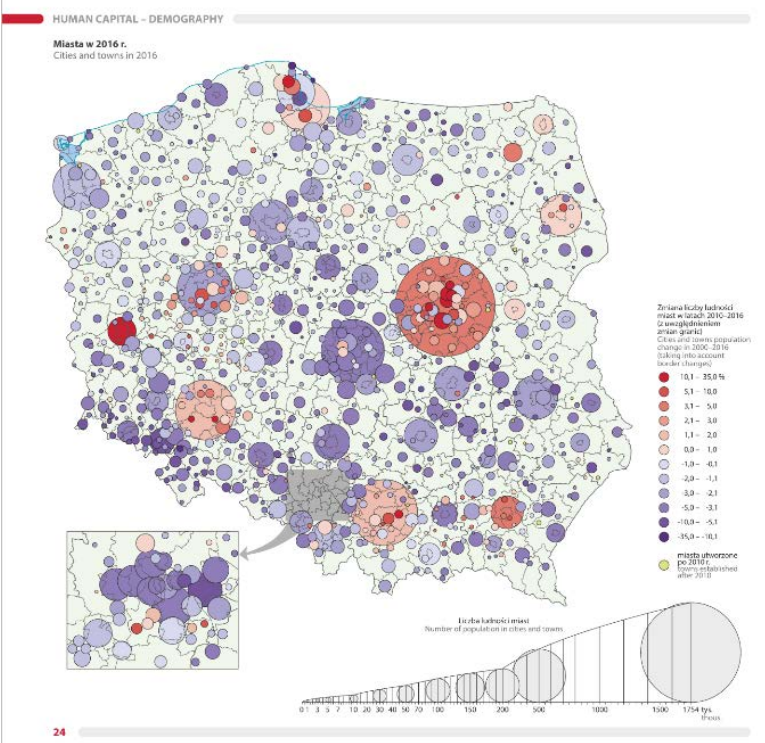

Figure 2. An example of a page with one large map of Poland from the Statistical atlas of Poland - p. 24: Cities and towns in 2016. (C) Statistics Poland 2018.

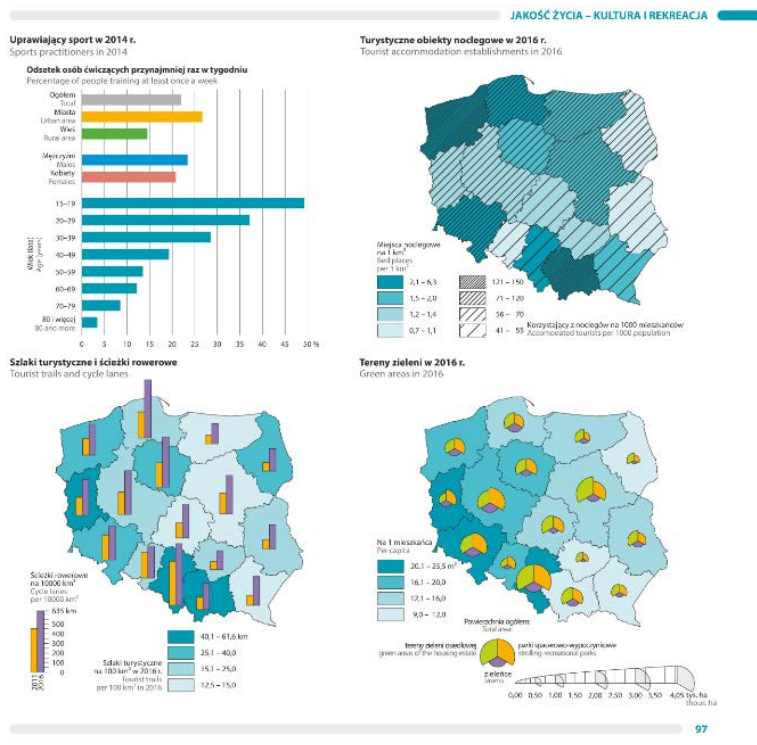

Figure 3. An example of a four-split page from the Statistical atlas of Poland - p. 97 related to tourism. (C) Statistics Poland 2018.

The following map scales are included in the atlas: a fullpage map of Poland - 1:3,800,000 (Figure 2), a map of
Poland covering of 1/4 page - 1:9,000,000 (Figure 3), a full-page map of Europe or the European Union $1: 21,500,000$ (Figure 4 ), a world map covering of $1 / 2$ page $-1: 200,000,000$.

The atlas consists of 216 pages, with 281 maps and 175 charts/graphs. In terms of numbers, the maps of Poland with the division into voivodships predominate - there are 134 such maps in the atlas (Figure 3 ). The next are fullpage maps of Poland with the division into communes (the third order administrative units, 41 maps) and powiats (the second order administrative units, 27 maps). Other maps of Poland in the atlas are the following: 5 maps with the division into NUTS level 3 units, 4 maps with the division into NUTS level 1 units, and 23 maps with other territorial divisions or without divisions at all (Figure 2). Among the maps of the European Union, 18 maps are divided into countries (Figure 4) and 11 are divided into NUTS level 2 units. All of the 18 maps of the world are divided into countries.

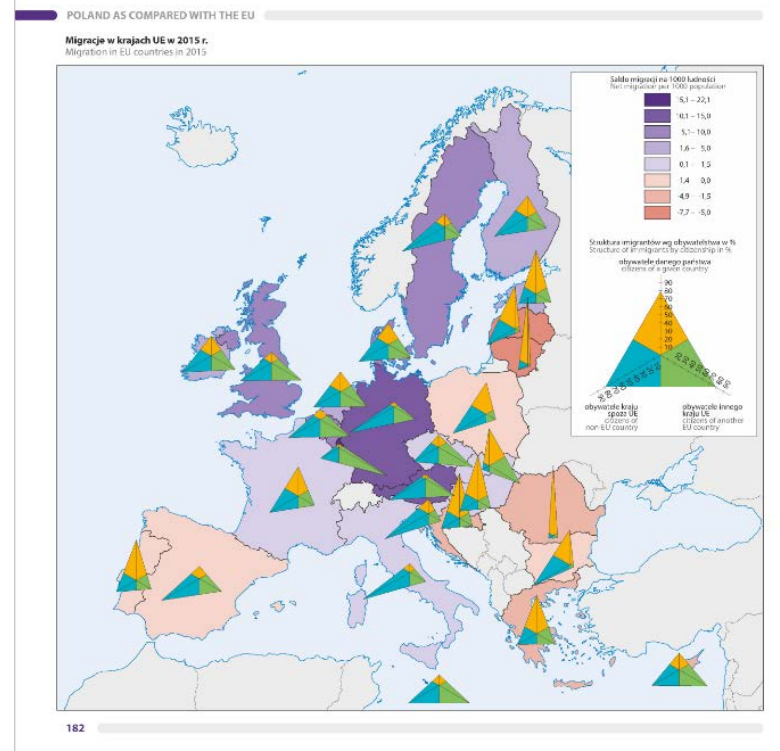

Figure 4. An example of a page with a map of the European Union from the Statistical atlas of Poland - p. 182: Migration in EU countries in 2015. (C) Statistics Poland 2018.

Maps made by using quantitative cartographic presentation methods predominate in the atlas. The only exception is the first section, in which the qualitative methods predominate (this section contains, among other things, the administrative map of Poland, the political map of Europe, maps of statistical divisions of Poland). Choropleth and diagram methods are the most frequently used on maps of the Statistical Atlas of Poland. These two quantitative methods may be observed on 263 maps (Figure 2, Figure 3 and Figure 4). Furthermore, on one map (the distribution of rural population) the dot method is used, and on 17 maps - the chorochromatic method (in 4 cases together with the signature method) is presented. Among the choropleth maps in the atlas, choropleth maps with a relation to an area dominate (231 maps); there are also two continuous choropleth maps, 18 complex choropleth maps and one structural-classification choropleth map. The using of 
diagram maps is also varied. Among these maps in the atlas, the most frequently used are: simple diagrams -82 times (bar ones - 73, pie ones - 9), structural diagrams 21 times (all pie diagrams), summary-structural diagrams - 11 times (bar ones - 2, pie ones - 9), complex diagrams -18 times, and others -20 times.

\section{Statistical atlases of voivodships}

In addition to the Statistical Atlas of Poland, 16 statistical atlases of voivodships were also published in 2018 (Figure 5). Atlases for individual voivodships have been prepared by relevant regional statistical offices. Management of this project was conducted by the Spatial and Environmental Surveys Department of Statistics Poland - it prepared the guidelines as well as headed the technical and substantive supervision. Moreover, some of the maps were prepared directly in the head office of Statistics Poland as well. The principles and the layout of atlases of individual voivodships are similar to those used in the Statistical Atlas of Poland. Atlases of voivodships consist of six thematic sections: Location and Administrative Division (with an administrative map of a voivodship, administrative map of Poland and political map of Europe), Human capital (divided into three parts: Demography, Education, Labour resources), Quality of life (divided into five parts: Infrastructure, Health care, Social welfare, Culture, Safety), Economy (divided into six parts: Regional accounts, Entrepreneurship, Public finance, Agriculture, Tourism, Road infrastructure), Environment, and Voivodship as Compared with EU NUTS 2 Regions (data for European Union statistical regions of NUTS level 2).

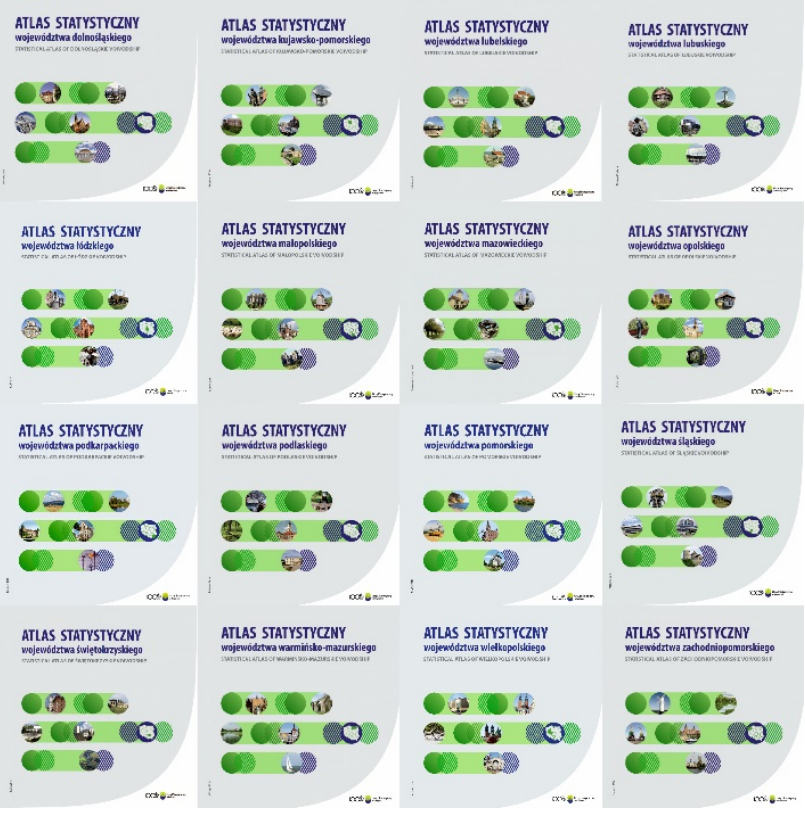

Figure 5. Covers of 16 statistical atlases of voivodships, published in 2018. (C) Statistics Poland 2018.

These atlases, due to different size of voivodships, were prepared on scales from 1:900,000 (Opolskie and Świętokrzyskie Voivodships) to 1:1,500,000 (Mazowieckie and Wielkopolskie Voivodships). The standard page contains a map of this voivodship divided into communes or powiats (Figure 6). The main topic of the page is presented on this map using the choropleth method only or the choropleth method combined with the diagram method (bar diagrams or pie diagrams). In addition, the map of Poland on a scale of 1:9,500,000 and in the division into voivodships is located on a page next to the map of the voivodship. This map has been made using the choropleth method only. Moreover, as a rule, on this map it is shown the same subject as on the map of the voivodship. In addition to these two maps, a chart thematically related to the map of the voivodship is usually placed. A definition explaining the terminology relevant to subject presented on maps is sometimes included on a page (e.g. median age of population).

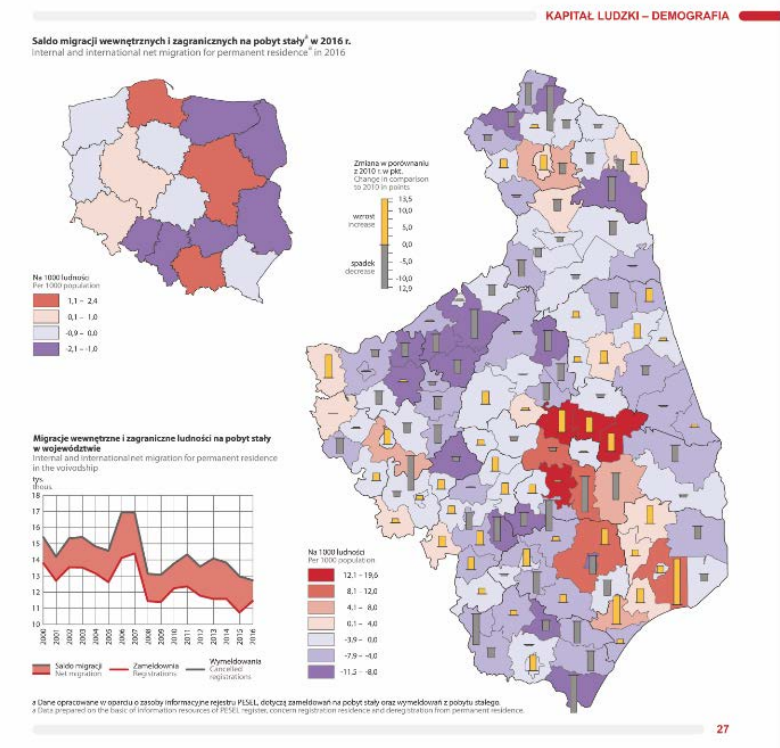

Figure 6. An example of content layout on a page of the statistical atlas of the voivodship - p. 27: Internal and international net migration for permanent residence in 2016 from the Statistical Atlas of Podlaskie Voivodship. (C) Statistics Poland 2018.

The assumed number of pages of the voivodship atlas is 104 with 165 maps: 76 maps of the voivodship, 76 maps of Poland, one administrative map of Poland on a scale of 1:3,800,000 and 12 maps of the European Union or Europe on a scale of $1: 21,500,000$. In the case of atlases of two voivodships, the final number of pages of the publications was slightly larger and amounted 108 pages due to the presentation of several additional topics (such as maritime economy).

\section{Conclusions}

Statistical atlases of voivodships and the Statistical Atlas of Poland count 1888 pages in total with 2934 maps, on which the development of the country, in close connection with regional and local conditions, as well as the situation in the European Union and in the world, is illustrated. Data sources used in the publication are information resources of public statistics from statistical surveys and from information systems provided to public statistics by external sources. To illustrate the phenomena in international comparisons, the databases of the European Commission (including Eurostat), OECD, World Bank and UN were used. The resources of the Head Office of Geodesy 
and Cartography, Eurostat, EuroGeographics AISBL and Natural Earth were used to develop base-maps.

The atlases published in 2018 are larger in number and volume than all the earlier atlas publications of Polish public statistics combined. Hopefully, they will become a valuable, interesting and user-friendly source of information on the socio-political situation of Poland (also on the background of the European Union and the World), its voivodships and their internal diversity.

All atlases are bilingual, Polish-English. Publications printing was co-financed from EU funds within the Operational Programme Technical Assistance 2014-2020. Atlases are also available free of charge in the PDF format on the website of Statistics Poland: https://stat.gov.pl/ statystyka-regionalna/publikacje-regionalne/podrecznikiatlasy/atlasy/.

\section{References}

Atlas demograficzny Polski - Demographic Atlas of Poland (2017). Warszawa: Główny Urząd Statystyczny.

Atlas statystyczny Polski - Statistical Atlas of Poland (2018). Warszawa: Główny Urząd Statystyczny.

Atlas statystyczny województwa dolnośląskiego - Statistical Atlas of Dolnośląskie Voivodship (2018). Wrocław: Urząd Statystyczny we Wrocławiu.

Atlas statystyczny województwa kujawsko-pomorskiego - Statistical Atlas of Kujawsko-Pomorskie Voivodship (2018). Bydgoszcz: Urząd Statystyczny w Bydgoszczy.

Atlas statystyczny województwa lubelskiego - Statistical Atlas of Lubelskie Voivodship (2018). Lublin: Urząd Statystyczny w Lublinie.

Atlas statystyczny województwa lubuskiego - Statistical Atlas of Lubuskie Voivodship (2018). Zielona Góra: Urząd Statystyczny w Zielonej Górze.

Atlas statystyczny województwa łódzkiego - Statistical Atlas of Łódzkie Voivodship (2018). Łódź: Urząd Statystyczny w Łodzi.

Atlas statystyczny województwa małopolskiego - Statistical Atlas of Małopolskie Voivodship (2018). Kraków: Urząd Statystyczny w Krakowie.

Atlas statystyczny województwa mazowieckiego - Statistical Atlas of Mazowieckie Voivodship (2018). Warszawa: Urząd Statystyczny w Warszawie.

Atlas statystyczny województwa opolskiego - Statistical Atlas of Opolskie Voivodship (2018). Opole: Urząd Statystyczny w Opolu.

Atlas statystyczny województwa podkarpackiego Statistical Atlas of Podkarpackie Voivodship (2018). Rzeszów: Urząd Statystyczny w Rzeszowie.

Atlas statystyczny województwa podlaskiego - Statistical Atlas of Podlaskie Voivodship (2018). Białystok: Urząd Statystyczny w Białymstoku.

Atlas statystyczny województwa pomorskiego - Statistical Atlas of Pomorskie Voivodship (2018). Gdańsk: Urząd Statystyczny w Gdańsku.
Atlas statystyczny województwa śląskiego - Statistical Atlas of Śląskie Voivodship (2018). Katowice: Urząd Statystyczny w Katowicach.

Atlas statystyczny województwa świętokrzyskiego Statistical Atlas of Świetokrzyskie Voivodship (2018). Kielce: Urząd Statystyczny w Kielcach.

Atlas statystyczny województwa warmińsko-mazurskiego - Statistical Atlas of Warmińsko-Mazurskie Voivodship (2018). Olsztyn: Urząd Statystyczny w Olsztynie.

Atlas statystyczny województwa wielkopolskiego - Statistical Atlas of Wielkopolskie Voivodship (2018). Poznań: Urząd Statystyczny w Poznaniu.

Atlas statystyczny województwa zachodniopomorskiego Statistical Atlas of Zachodniopomorskie Voivodship (2018). Szczecin: Urząd Statystyczny w Szczecinie.

Atlas statystyczny zagadnień społecznych [Statistical atlas of social issues] (2012). Szczecin: Urząd Marszałkowski Województwa Zachodniopomorskiego.

Narodowy Spis Powszechny Ludności i Mieszkań 2011. Atlas powiatów i gmin województwa mazowieckiego [National Census of Population and Housing 2011. Atlas of counties and communes of Mazowieckie Voivodship] (2014). Warszawa: Urząd Statystyczny w Warszawie.

Powszechny Spis Rolny 2010. Atlas. Produkcja rolnicza na obszarach wiejskich województwa mazowieckiego [Agricultural Census 2010. Atlas. Agricultural production in rural areas of Mazowieckie Voivodship] (2013). Warszawa: Urząd Statystyczny w Warszawie.

Rzeczpospolita Polska. Atlas statystyczny - La République Polonaise. Atlas statistique [Republic of Poland. Statistical Atlas] (1930). Warszawa: Główny Urząd Statystyczny Rzeczypospolitej Polskiej.

Statystyczny atlas województwa lubelskiego 2012 Statistical atlas of Lubelskie Voivodship 2012 (2014). Lublin: Urząd Statystyczny w Lublinie.

Statystyczny atlas województwa małopolskiego 2016 [Statistical atlas of Małopolskie Voivodship 2016] (2016). Kraków: Urząd Statystyczny w Krakowie.

Statystyczny atlas województwa warmińsko-mazurskiego 2005 [Statistical atlas of Warmińsko-Mazurskie Voivodship 2005] (2016). Olsztyn: Urząd Statystyczny w Olsztynie.

Stępiński J. (ed.) (1970). Atlas statystyczny [Statistical Atlas]. Warszawa: Główny Urząd Statystyczny. 